\title{
Post-nesting movements and feeding grounds of a resident East Pacific green turtle Chelonia mydas population from Costa Rica
}

\author{
Gabriela S. Blanco ${ }^{1, *}$, Stephen J. Morreale ${ }^{2}$, Helen Bailey ${ }^{3}$, Jeffrey A. Seminoff ${ }^{4}$, \\ Frank V. Paladino ${ }^{5}$, James R. Spotila ${ }^{1}$ \\ ${ }^{1}$ Department of Biology, Drexel University, Philadelphia, Pennsylvania 19104, USA \\ ${ }^{2}$ Department of Natural Resources, Cornell University, Ithaca, New York 14853, USA \\ ${ }^{3}$ Chesapeake Biological Laboratory, University of Maryland Center for Environmental Science, Solomons, Maryland 20688, USA \\ ${ }^{4}$ NOAA - National Marine Fisheries Service, Southwest Fisheries Science Center, La Jolla, California 92037, USA \\ ${ }^{5}$ Department of Biology, Indiana-Purdue University, Fort Wayne, Indiana 46805-1499, USA
}

\begin{abstract}
Satellite telemetry has helped reveal migratory movements of sea turtles. We attached satellite transmitters (MK10 Pat Tags) to 10 post-nesting East Pacific green turtles Chelonia mydas from Nombre de Jesús, Costa Rica (in 2006, 2007 and 2009) to track their movements, identify their foraging grounds, and elucidate their foraging behavior. Location data were analyzed by applying a switching state-space model to obtain daily position estimates and to differentiate between 2 behavioral modes (migrating and foraging). All post-nesting movements were along coastal routes ranging up to $1086 \mathrm{~km}$ from the nesting beach. Of the 10 turtles, 6 remained local residents of Costa Rica foraging in the Gulf of Papagayo $(\mathrm{N}=2)$ and the Gulf of Santa Elena $(\mathrm{N}=4)$. One individual moved southwards to the Gulf of Panama, and 3 other turtles migrated northwards to waters off the Gulf of Fonseca in northern Nicaragua, with one continuing its foraging movements northwards to coastal Guatemala. Home ranges during foraging varied widely among individuals, and the calculated size of feeding grounds ranged from 315 to $18335 \mathrm{~km}^{2}$, the latter being the largest reported for this species. The fact that members of this nesting population inhabit coastal waters makes them vulnerable to human activities along the coasts of Central America. Our findings highlight the importance of Costa Rica and the coastal waters of Central America for the survival of the Endangered Costa Rican green turtles.
\end{abstract}

KEY WORDS: East Pacific green turtle $\cdot$ Chelonia mydas $\cdot$ Migration $\cdot$ Costa Rica $\cdot$ Foraging grounds $\cdot$ Satellite telemetry $\cdot$ Switching state-space model $\cdot$ Black turtle

Resale or republication not permitted without written consent of the publisher

\section{INTRODUCTION}

East Pacific green turtles Chelonia mydas belong to a distinct group of this Endangered species (IUCN 2010), inhabiting waters in tropical and sub-tropical regions throughout the eastern Pacific (Seminoff et al. 2002a). They range from southern California, USA (Eguchi et al. 2010), to Chile, and west to the Galapagos Islands, with nesting grounds distributed throughout this range. Based on the number of females and the numbers of nests in a season, the most important nesting grounds identified in the Pacific are found at Michoacán, Mexico (AlvaradoDíaz et al. 2001), the Galapagos Islands (Green 1984), the Revillagigedo Archipelago, Mexico (Holroyd \& Trefry 2010), and Nombre de Jesús, Costa Rica (Blanco et al. 2012). Post-nesting females display a similarly broad array of migratory movements. For 
example, post-nesting Michoacán green turtles migrate both northwards and southwards along the coast of Central America (Alvarado \& Figueroa 1992). Tag returns and satellite telemetry from post-nesting Galapagos green turtles have revealed at least 3 different migratory strategies (Green 1984, Seminoff et al. 2008), including (1) some females migrating to the coast of Central America (Green 1984), (2) others remaining resident among the Galapagos Islands, and (3) a third group migrating to oceanic waters to forage (Seminoff et al. 2008).

In the eastern Pacific, juvenile and adult green turtles mainly forage in coastal areas, including estuaries, lagoons (Bjorndal 1997), and nearshore insular habitats (Amorocho \& Reina 2007). Recent studies have demonstrated that they also forage in high-sea waters (Quiñones et al. 2010). Their diet consists principally of seagrass and red and green algae; however, they also forage on invertebrates and gelatinous prey (Seminoff et al. 2002b, Seminoff \& Jones 2006). This is not universal, however, as recent studies have demonstrated that adult green turtles also forage in open waters offshore of Peru, where they feed on a diet dominated by jellyfish, mollusks, and crustaceans (Quiñones et al. 2010).

In the middle of their range, East Pacific green turtles nest in Costa Rica (Richard \& Hughes 1972, Cornelius 1976). Anecdotal information suggests that turtles in this region are subjected to capture in artisanal longlines and gill nets (S. Friederichs pers. comm.). In addition, it is well known that poaching of green turtle eggs is rampant on many beaches in western Costa Rica (Blanco 2010). Nevertheless, limited scientific information is available for Costa Rican green turtles, and their migration routes and foraging grounds remain completely unknown. Recent studies have focused more attention on the potential importance of conservation efforts on Costa Rican nesting beaches (Blanco et al. 2012). However, to better protect this Endangered species from threats in the ocean, it is crucial that we know more about their migration routes, their foraging grounds, and their behavior at sea, where they spend most of their life.

The objectives of this study were to determine the migration routes and elucidate information on the foraging grounds of the East Pacific green turtles that nest in Nombre de Jesús, Costa Rica. Through this research we aimed to understand the migratory strategies of this population and compare them with the strategies of green turtles nesting in other rookeries within the eastern Pacific. We also attempted to determine areas of importance for regional conserva- tion and to identify human activities that could potentially be detrimental to this population.

\section{MATERIALS AND METHODS}

We attached satellite transmitters (Wildlife Computers Mk-10 PAT, pop-up archival transmitting tag) to 9 green turtles Chelonia mydas nesting on Nombre de Jesús $\left(10^{\circ} 23^{\prime} 30^{\prime \prime} \mathrm{N}, 85^{\circ} 50^{\prime} 07^{\prime \prime} \mathrm{W}\right)$ and 1 green turtle on the neighboring beach, Playa Zapotillal in Guanacaste Province, Costa Rica (Fig. 1). The PAT tags were configured to transmit opportunistically, so we could obtain real-time location data as frequently as possible, while the turtles were at sea. From 2006 to 2009, satellite transmitters were attached to 10 female green turtles before they migrated from the nesting beach (see Table 1). During the nesting season, we patrolled the beach at night to intercept turtles during their final nesting event of the season and prior to migration. In assessing the reproductive status of each turtle we used a portable real-time ultrasound scanner to verify that the last clutch of the season was being laid (Aloka SSD-500) (Blanco et al. 2012). This ensured that the turtles would leave the area after nesting and not be subjected to poachers on the beach or fisherman in nearshore waters.

Each selected turtle was also scanned for a passive integrated transponder (PIT) tag. PIT tags were inserted in the right front flipper of those turtles found not to already have a PIT tag for later possible identifi-

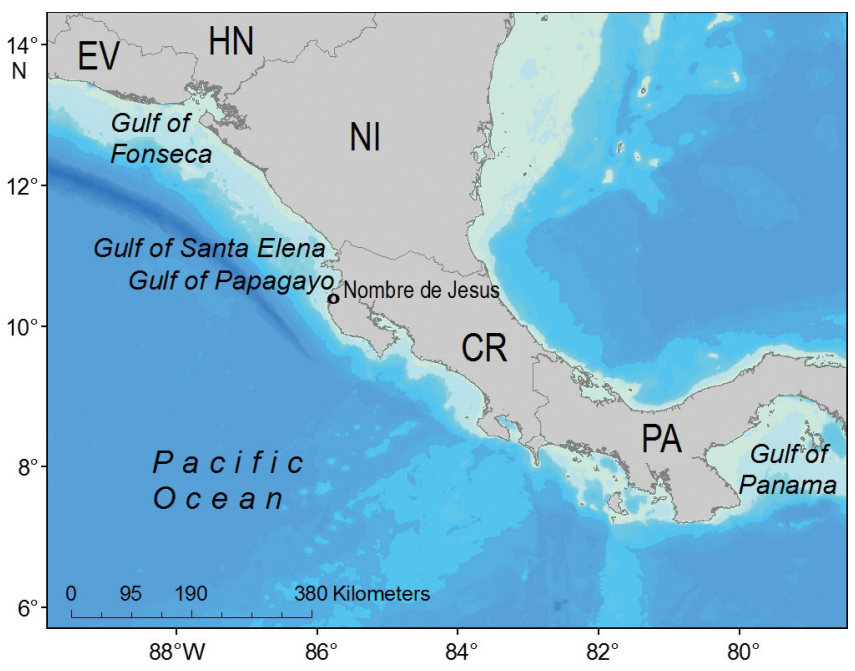

Fig. 1. Study area. Satellite transmitters were attached to post-nesting East Pacific green turtles Chelonia mydas at Nombre de Jesús beach $\left(10^{\circ} 23^{\prime} 30^{\prime \prime} \mathrm{N}, 8^{\circ} 50^{\prime} 07^{\prime \prime} \mathrm{W}\right)$, Costa Rica (CR). EV: El Salvador; HN: Honduras; NI: Nicaragua; PA: Panama 
cation. Using a flexible tape, we measured the curved carapace length $\left(\mathrm{CCL}_{;} \pm 0.5 \mathrm{~cm}\right)$ from the nuchal notch to the posterior tip of the supracaudal scute and curved carapace width (CCW) at the widest point of the carapace. All turtles were examined to ensure they did not have any external abnormalities that might have affected behavior.

\section{Satellite transmitter attachment}

We followed a modified methodology used by Morreale et al. (1996) described in Morreale (1999) to attach a satellite transmitter to the turtle by a short lanyard. First, we cleaned a supracaudal scute with $70 \%$ alcohol and made a $3 \mathrm{~mm}$ diameter incision with a sterile drill bit (battery-powered electric drill). Immediately after the incision, we applied lidocaine and inserted sterile surgical tubing in the hole. We positioned plastic buttons above and below the carapace to avoid abrasion of the carapace and passed a flexible lanyard (monofilament fishing line, $400 \mathrm{lb}$ [ca. $181 \mathrm{~kg}$ ] test) through the hole. The transmitter was then secured to the lanyard with a metal crimp and a swivel. To prevent entanglement, the lanyard length was kept very short, and, to avoid long-term encumbrance, swivels and crimps were corrodible, designed to break away with age. The attachment process took 7 to $10 \mathrm{~min}$, and was performed when the turtle was covering the nest after laying eggs.

\section{Satellite transmitters}

Standard MK-10 PAT Tags (Wildlife Computers) were customized by us to slightly increase buoyancy and to ensure that the transmitter assumed an upright position when the turtle stopped forward movement. Fitted with a small syntactic foam collar, each satellite transmitter weighed $\sim 115 \mathrm{~g} \quad(\sim 0.2 \%$ of the turtle mass). More importantly, they were hydrodynamically shaped to minimize drag and trailed behind the turtle in what we calculated to be the turtle's slipstream as it swam (Logan \& Morreale 1994). The transmitters had a buoyancy of approximately $36 \mathrm{~g}$, which was sufficient to bring the antenna of the transmitter to the surface when the turtle surfaced to breathe. Tags were programmed with duty cycles of $10 \mathrm{~h}$ on:14 h off daily to optimize battery life, transmitting $5 \mathrm{~h}$ during the night and $5 \mathrm{~h}$ during daylight. The archival transmitter sampled and summarized diving data (dive depth, dive duration, and time at depth) stored in categorized bins - dive depths: 5, 10,
$15,20,25,30,35,40,45,50,75,100$, and $200 \mathrm{~m}$ and dive durations: $2,5,10,20,30,40,50,60$ and $90 \mathrm{~min}$.

\section{Track analysis}

All turtle locations were obtained through the Argos satellite telemetry system (www.ARGOSsystem.org). A Bayesian switching state-space model (SSSM) (Jonsen et al. 2007) was applied to all raw Argos-acquired locations. The SSSM allowed us to generate daily positions and construct an individual track for each turtle $(\mathrm{N}=10)$. The transition equation that modeled the movement dynamics (Patterson et al. 2008) included a process model for each of 2 behavioral modes (Jonsen et al. 2005). Behavioral Mode 1 represented transiting behavior, and Mode 2 represented foraging behavior (or area-restricted search, ARS behavior) (Bailey et al. 2008, 2009). The SSSM was fitted using the R software package (R Development Core Team 2008) and WinBUGS software (Lunn et al. 2000). The model was run with 2 chains for 30000 Markov Chain Monte Carlo (MCMC) samples with a 10000 burn-in (thin = 5).

\section{Post-nesting movements}

For all spatial referencing, mapping, and plotting of turtle tracks, and range and habitat-use analyses, we used ArcGIS Version 9.3 (www.esri.com). Based on daily locations estimated with the SSSM, for each turtle we calculated distance traveled per day and total distance traveled during migration. We excluded from this analysis only the turtles for which migration was tracked for $<2$ d. To determine whether turtle size influenced migration distance, we tested for correlation between the CCL of the tagged turtles and both the total distances traveled and the mean daily distance traveled during migration.

\section{Foraging areas}

Once behavioral modes were determined from the SSSM, we separated the locations isolating the ARS behavior to analyze the areas used by the turtles during foraging. We used $100 \%$ minimum convex polygons (MCP) to analyze the ranges during foraging for each individual. The MCPs were calculated using Hawth's Analysis Tools for ArcGIS. MCP areas were based on the minimum distance of outer locations for each turtle in the foraging areas, including all loca- 
tions classified as ARS behavior. Additionally, we performed a fixed kernel density analysis (KDA) using the least-squares-cross-validation method (LSCV) to calculate the smoothing factor (Worton 1989). Core areas were determined by the 50 and $95 \%$ utilization distribution (UD). For these analyses, we used Home Range Tools for ArcGIS (Rodgers et al. 2005). The KDA was performed individually for each female $(\mathrm{N}=8)$ to ensure that the variation in the duration of the transmissions did not influence the analysis.

\section{Dive behavior}

Dive depths and dive durations for each individual were recorded and stored by the PAT tags and summarized into bins, which were transmitted later through the Argos satellite system. Thus, frequency histograms of accumulated diving activity were condensed into 14 depth and 14 duration categories, which we preselected. Each histogram was summarized in $4 \mathrm{~h}$ intervals, which allowed us to compare diving patterns for different segments of the day and between day and night. Using these behavioral histograms, we also calculated the proportion of depth of dives and dive duration during migration and foraging for each turtle (1-way ANOVA). In addition, we compared the diving depths of turtles among different foraging areas. Statistical analyses were performed using SPSS Statistics Software (www-01. ibm.com/software/analytics/spss/). Data were transformed, when necessary, using arcsine transformation, to meet the assumption of normal distribution. Statistical significance was set at the 0.05 level.

\section{RESULTS}

\section{Post-nesting movements}

All 10 of the post-reproductive turtles initiated post-nesting movements soon after the attachment of satellite transmitters, and did not return to the nesting beach during that season. The duration of transmissions from the satellite transmitters ranged from 25 to $102 \mathrm{~d}$ (mean $\pm \mathrm{SD}=62.2 \pm 27.9 \mathrm{~d}$ ). Even though the batteries of the transmitters lasted for a shorter time than expected, the time was sufficient to track 9 of the 10 turtles to the foraging areas and recover information on turtle foraging for an average of $55 \mathrm{~d}$ (range $=18$ to $89 \mathrm{~d}$ ). The movements of all turtles, whether of short or long duration, conveyed them from the nesting beach to neritic foraging grounds, at net distances from 0 to $1086 \mathrm{~km}$ away (Table 1). Most of the turtles moved northwards after nesting; 2 individuals took up residence nearby; and 1 of the 10 turtles moved southwards, ending up in coastal waters of Panama. This turtle (Turtle 2) exhibited the longest migration, traveling approximately $1086 \mathrm{~km}$ southwards (Fig. 2). Three of the northward moving turtles migrated through Nicaraguan waters (approximately 270,390 , and $430 \mathrm{~km}$, respectively); one settled into a feeding pattern in the region off the Gulf of Fonseca, and one foraged in an area from southern Guatemala to northern Nicaragua (Fig. 3). Four other turtles traveled northwards, migrating only short distances (from 62 to $98 \mathrm{~km}$ ) to the Gulf of Santa Elena in northern Costa Rica (Fig. 4). Two turtles stayed in the vicinity of the nesting beach and took up residency in the nearby Gulf of Papagayo (Fig. 5), approximately $5 \mathrm{~km}$ north of the nesting beach, and during this time

Table 1. Chelonia mydas. Post-nesting movements of East Pacific green turtles with satellite transmitters attached at Nombre de Jesús, Costa Rica. CCL: curved carapace length; total tracking: duration of satellite transmissions; migration: calculated number of days individuals took to reach foraging areas; track length: length of track covered exclusively during migration; foraging: track duration while on foraging grounds; MCPs: total area of minimum convex polygons (MCPs were created based on all locations within foraging areas). na: not available

\begin{tabular}{|c|c|c|c|c|c|c|c|c|}
\hline Turtle ID & $\begin{array}{c}\text { Date } \\
\text { (dd/mm/yy) }\end{array}$ & $\begin{array}{l}\text { CCL } \\
(\mathrm{cm})\end{array}$ & $\begin{array}{c}\text { Total } \\
\text { tracking }(\mathrm{d})\end{array}$ & $\begin{array}{l}\text { Foraging } \\
\text { ground }\end{array}$ & $\begin{array}{l}\text { Migration } \\
\text { (d) }\end{array}$ & $\begin{array}{c}\text { Track length } \\
(\mathrm{km})\end{array}$ & $\begin{array}{l}\text { Foraging } \\
\text { (d) }\end{array}$ & $\begin{array}{l}\mathrm{MCP} \\
\left(\mathrm{km}^{2}\right)\end{array}$ \\
\hline 1 & $17 / 10 / 06$ & 77.5 & 29 & Off Nicaragua ${ }^{a}$ & 29 & 430 & na & na \\
\hline 2 & $24 / 08 / 07$ & 91.4 & 70 & Gulf of Panama & 26 & 1086 & 45 & 315 \\
\hline 3 & $16 / 01 / 09$ & 78.1 & 54 & Off Nicaragua $^{\mathrm{a}}$ & 17 & 390 & 33 & 4927 \\
\hline 4 & $24 / 01 / 09$ & 84.0 & 63 & Gulf of Papagayo & 0 & 0 & 58 & 1130 \\
\hline 5 & $10 / 09 / 09$ & 87.7 & 89 & Gulf of Elena & 3 & 66 & 84 & 1173 \\
\hline 6 & $23 / 10 / 09$ & 88.0 & 80 & Off Nicaragua $^{a}$ & 10 & 270 & 71 & 12061 \\
\hline 7 & $25 / 10 / 09$ & 81.4 & 25 & Gulf of Papagayo & 0 & 0 & 18 & 598 \\
\hline 8 & $27 / 10 / 09$ & 86.0 & 26 & Gulf of Elena & 3 & 98 & 18 & 3035 \\
\hline 9 & $13 / 11 / 09$ & 82.5 & 84 & Gulf of Elena & 1 & 77 & 77 & 18335 \\
\hline 10 & 18/11/09 & 84.4 & 102 & Gulf of Elena & 1 & 62 & 89 & 2477 \\
\hline
\end{tabular}




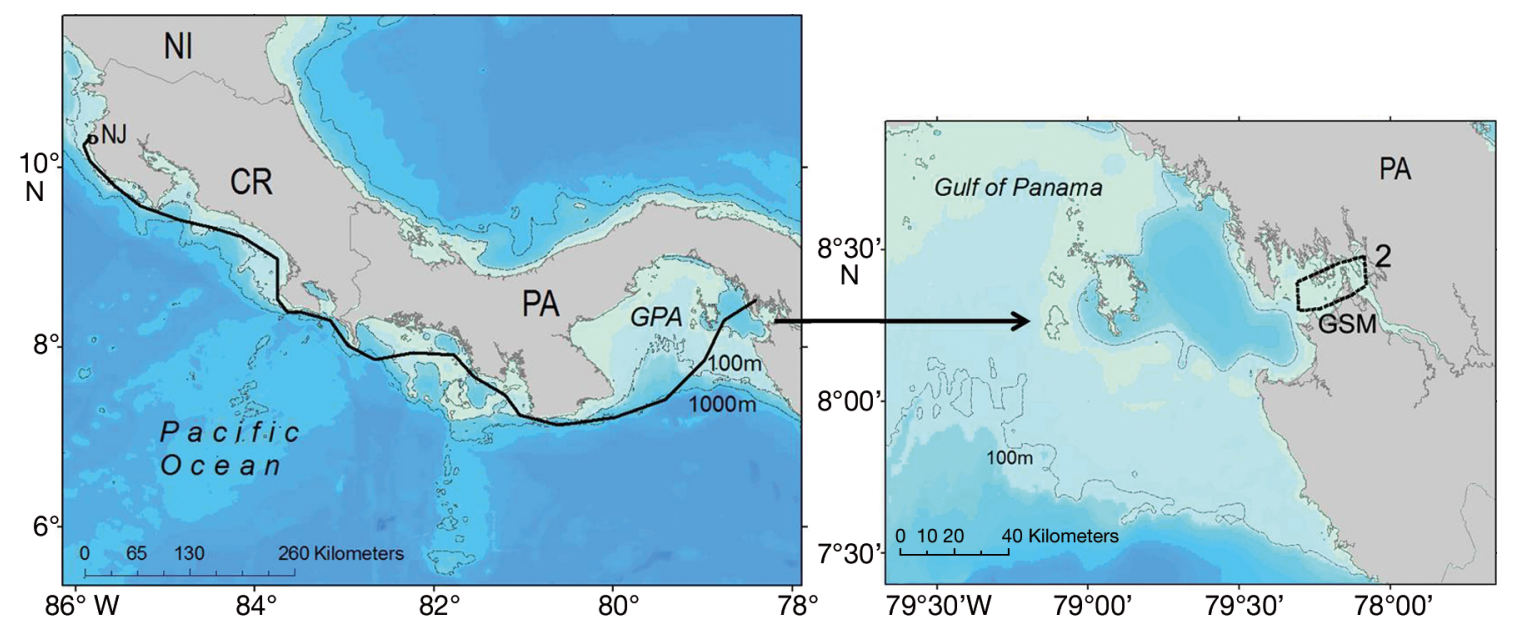

Fig. 2. Chelonia mydas. Post-nesting movement of 1 East Pacific green turtle from Nombre de Jesús (NJ), Costa Rica (CR). This individual (Turtle 2) migrated to the Gulf of Panama (GPA, approximately $1086 \mathrm{~km}$ ). Dashed line indicates the foraging area represented by $100 \%$ minimum convex polygon (MCP). MCP includes all locations for Turtle 2 during foraging (arearestricted search behavior). NI: Nicaragua; PA: Panama; GSM: Gulf of San Miguel
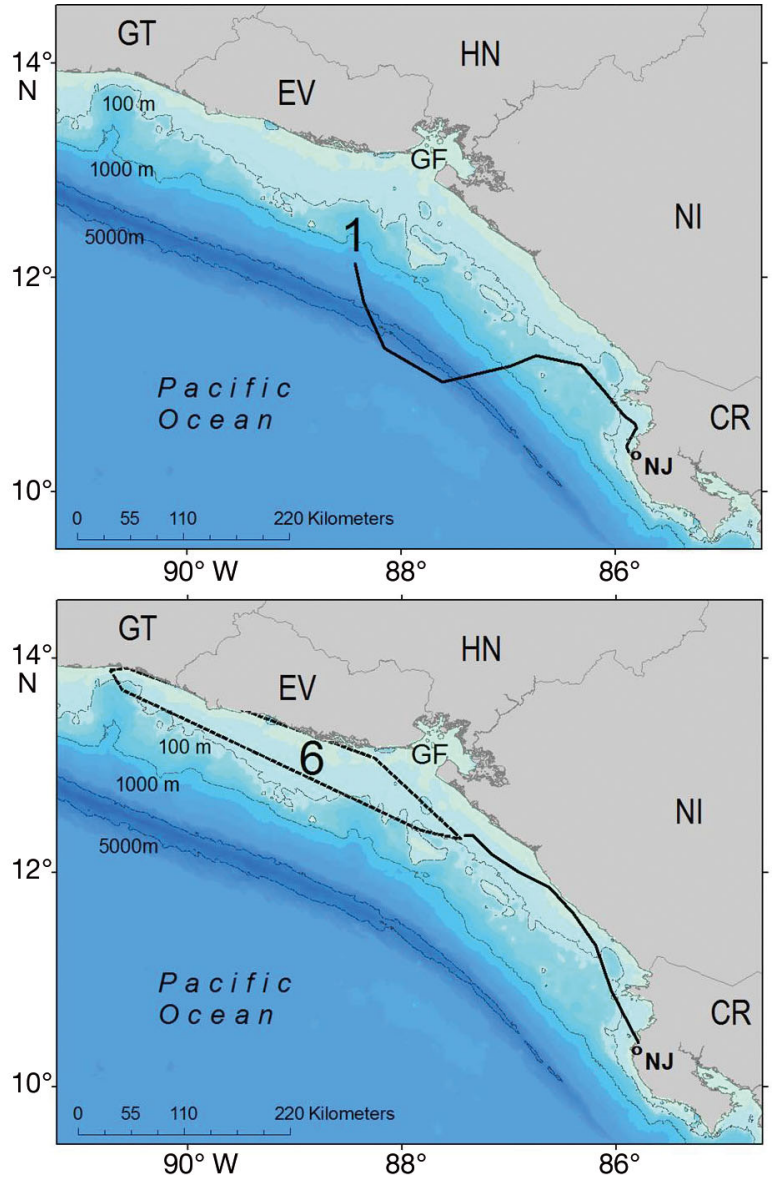

there was no record or other indication of the turtles going to any beach within the Gulf of Papagayo.

Turtle size did not appear to influence the magnitude of migratory movement after nesting was com-

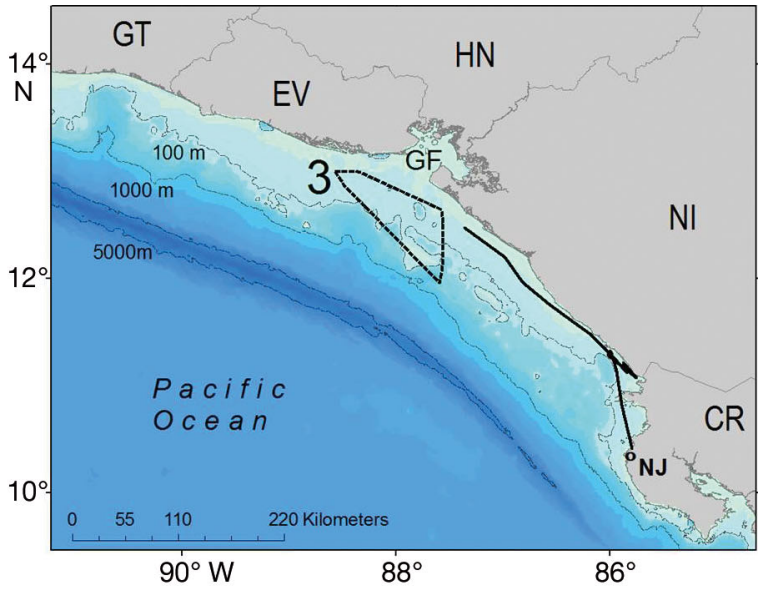

Fig. 3. Chelonia mydas. Post-nesting movements of 3 East Pacific green turtles from Nombre de Jesús (NJ), Costa Rica (CR). Turtles 1, 3, and 6 migrated (approximately 430, 390, and $270 \mathrm{~km}$, respectively) to waters off northern Nicaragua. Dashed lines for Turtles 3 and 6 indicate the foraging areas represented by $100 \%$ minimum convex polygons (MCP) which were located in waters off the Gulf of Fonseca (GF) and from southern Guatemala (GT) to northern Nicaragua (NI), respectively. MCPs include all locations for individual turtles during foraging (area-restricted search behavior). EV: El Salvador; HN: Honduras

pleted. There was no significant correlation between CCL and the length of the track (Pearson's correlation: $r=0.3 p=0.380, N=6$ ). Nor was there an apparent relationship between size and speed of travel. 

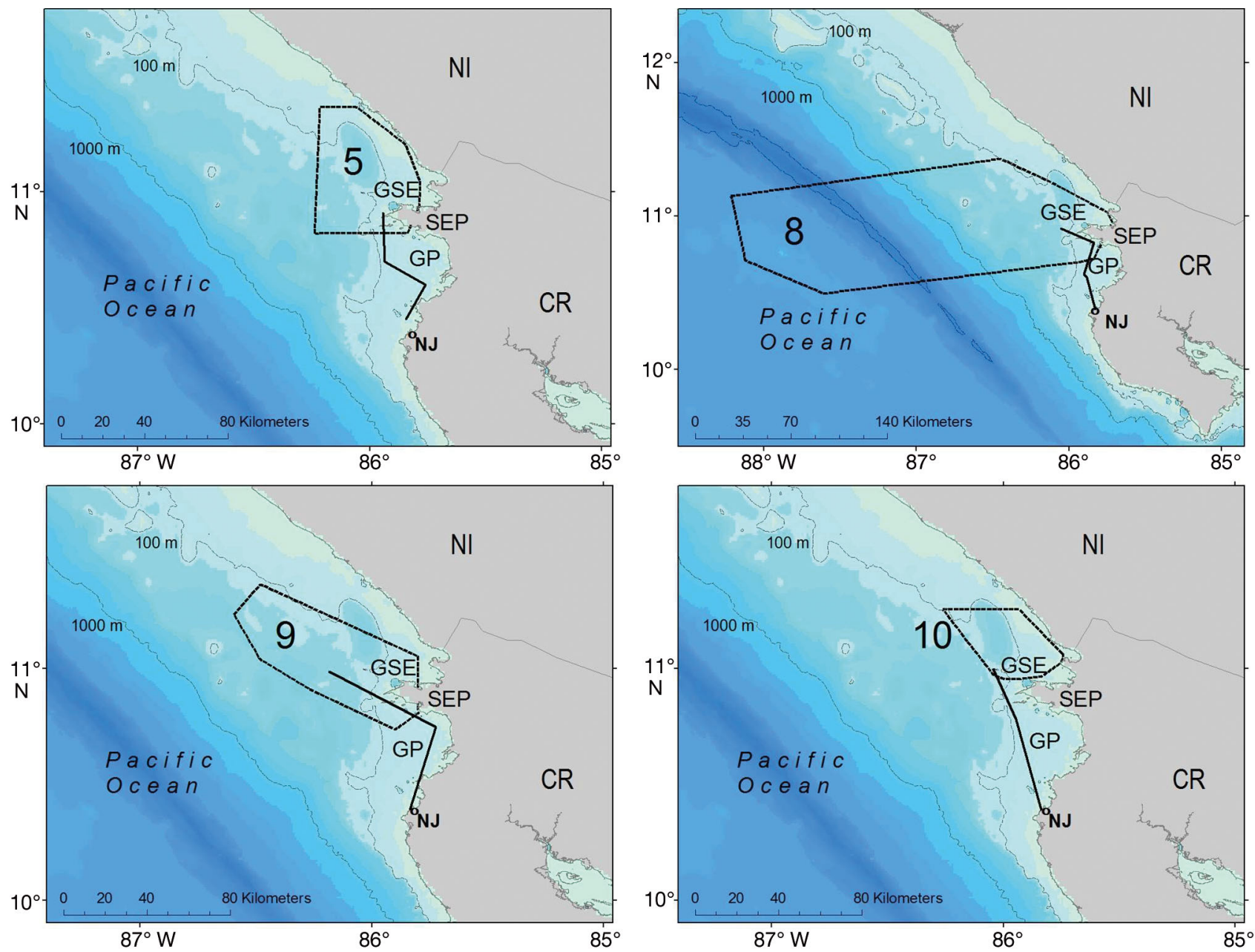

Fig. 4. Chelonia mydas. Post-nesting movements of 4 East Pacific green turtles from Nombre de Jesús (NJ), Costa Rica (CR). Turtles 5, 8, 9, and 10 performed short post-nesting movements to the Gulf of Santa Elena (GSE), approximately $75 \mathrm{~km}$ from the nesting beach. Dashed lines indicate the foraging areas represented by $100 \%$ minimum convex polygons (MCP). MCPs include all locations for individual turtles during foraging (area-restricted search behavior). NI: Nicaragua; SEP: Santa Elena Peninsula; GP: Gulf of Papagayo
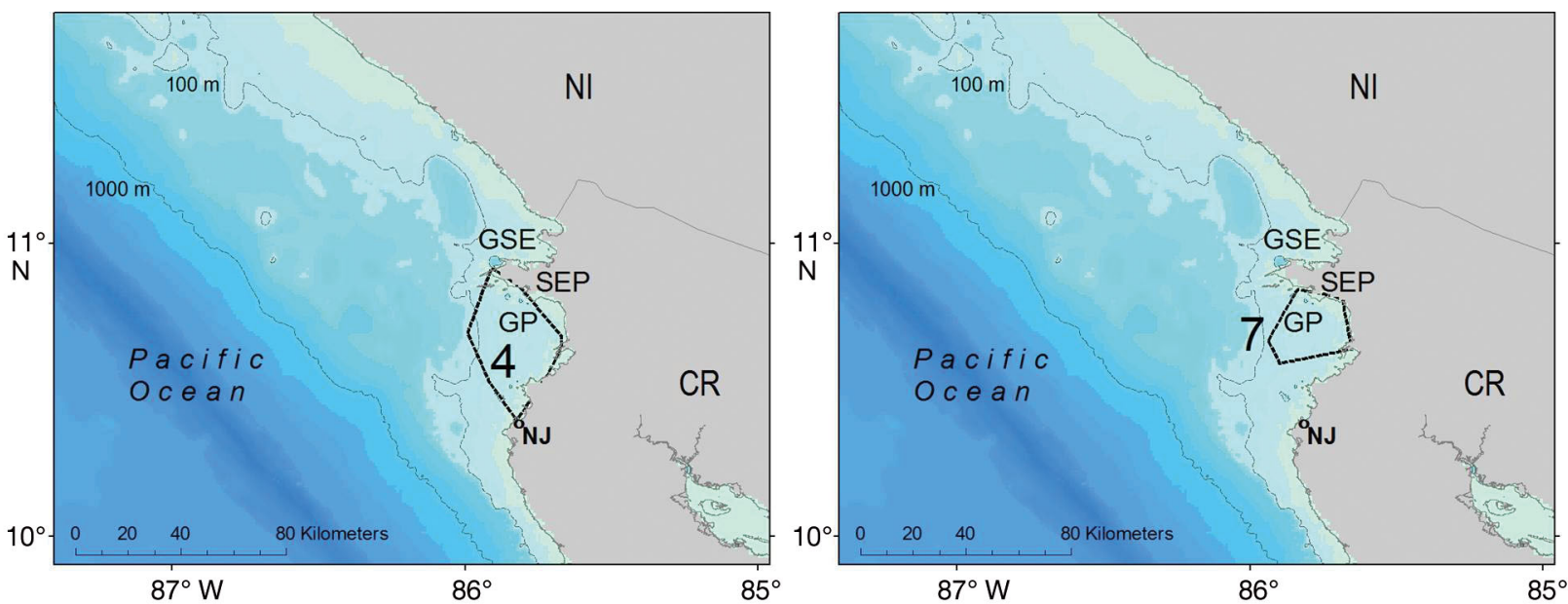

Fig. 5. Chelonia mydas. Foraging areas of 2 East Pacific green turtles from Nombre de Jesús (NJ), Costa Rica (CR), represented by $100 \%$ minimum convex polygons (MCP, dashed lines). Each MCP includes all locations for individual turtles during foraging. Although Turtles 4 and 7 moved north of the nesting beach they stayed within the Gulf of Papagayo (GP), demonstrating local residency. NI: Nicaragua; GSE: Gulf of Santa Elena; SEP: Santa Elena Peninsula 
The mean daily net distance during migration was calculated to be $37.0 \mathrm{~km}( \pm 8.4 \mathrm{SD})$, and was not significantly correlated with CCL (Pearson's correlation: $\mathrm{r}=0.599, \mathrm{p}=0.209, \mathrm{~N}=6$ ).

\section{Foraging areas}

At least 9 of the 10 tagged turtles reached foraging areas. Satellite transmissions were received from Turtle 1 for $29 \mathrm{~d}$ and ceased while the turtle was still moving steadily northwards. Once the turtles reached foraging grounds, the calculated area of their MCPs ranged from 315 to $18335 \mathrm{~km}^{2}$ (Table 1, Figs. 2 to 5). Interestingly, there was no significant correlation between the number of days classified as foraging and the area of the polygons (Pearson's correlation: $r=0.352, p=0.353, N=9$ ). In addition, the size of each polygon was not significantly correlated with the foraging area (Pearson's correlation: $r=0.133, p=$ $0.733, \mathrm{~N}=9$ ). In all, we identified 4 separate coastal foraging grounds for this nesting population. The most northern of the foraging areas extended from off the coast of southern Guatemala to northern Nicaragua. This area was somewhat elongated, because turtles changed from migratory to ARS behavior when they reached the waters off northern Nicaragua. Two of the foraging areas were in northern Costa Rica waters: one in the Gulf of Santa Elena and another in the Gulf of Papagayo. The southernmost foraging area was in the westernmost portion of the Gulf of Panama. Combined, the distribution of observed foraging grounds highlights the importance of the coast of Central America for this rookery located in northwestern Costa Rica.

Although the northward-migrating turtles switched to ARS behavior near the Gulf of Fonseca, none of the turtles foraged inside the gulf. Instead, they adopted what appeared to be a coastal feeding strategy. This was in sharp contrast to the individual that migrated to the Gulf of Panama that took up residence for the remainder of the track ( $45 \mathrm{~d}$ more until transmissions ceased) in the sheltered waters of the Gulf of San Miguel (Fig. 2). For the turtles foraging in the area of the Gulf of Santa Elena and the Gulf of Papagayo in Costa Rica, the KDA demonstrated that the main areas used included a mixture of both nearshore and offshore waters (Fig. 6). The $50 \%$ UD in the Gulf of Papagayo included approximately $250 \mathrm{~km}^{2}$, which represented about $30 \%$ of the total area of the gulf. In the Gulf of Santa Elena, the $50 \%$ UD of approximately $300 \mathrm{~km}^{2}$ extended far offshore, but corresponded to about $60 \%$ of the gulf's area. Turtles for-

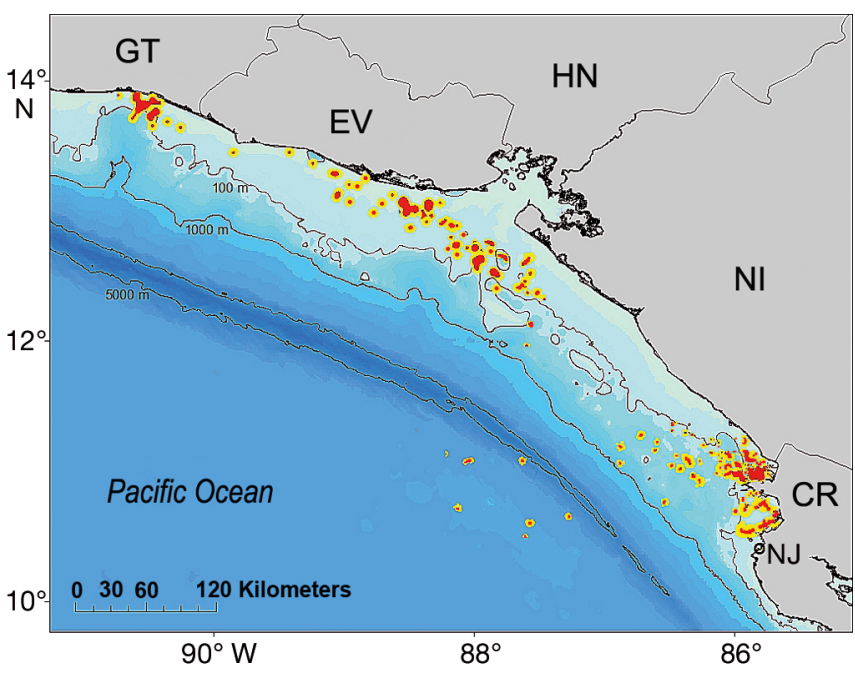

Fig. 6. Chelonia mydas. Fixed kernel density analysis (KDA) for 8 East Pacific green turtles from Nombre de Jesús (NJ), Costa Rica (CR), during foraging. The KDA was performed individually for each turtle because of the differences in track duration. Red: $50 \%$ utilization distribution (UD); yellow: 95\% UD. GT: Guatemala; EV: El Salvador; HN: Honduras; NI: Nicaragua

aging along the coast off northern Nicaragua, Honduras, El Salvador, and southern Guatemala occupied a substantially wider range $\left(950 \mathrm{~km}^{2}, 50 \% \mathrm{UD}\right)$. Daily movements during foraging (mean $\pm \mathrm{SD}=12.8$ $\pm 3.4 \mathrm{~km}$ ) were not significantly correlated to turtle size (Pearson's correlation: $r=-0.80, p=0.838$, $\mathrm{N}=9$ ).

\section{Dive behavior}

When all dive data were pooled together, we found significant differences among the overall duration of dives (ANOVA: $F=3.125$; df $=8,108 ; \mathrm{p}=0.003$; $\mathrm{N}=9$ ), with 2 min dives and 40 min dives being the most frequent behaviors observed (Fig. 7a). However, a Bonferroni post hoc multiple comparison test revealed significant differences only between 2 and $90 \mathrm{~min}$, and 40 and $90 \mathrm{~min}(\mathrm{p}=0.010$ and $\mathrm{p}=0.011$, respectively). There was no significant difference (1way ANOVA: $F=1.218$; $\mathrm{df}=8,108 ; \mathrm{p}=0.295$ ) in the mean duration of dives between migration and foraging behaviors. However, the distribution of dive durations during foraging appeared a little more uniform than during migration, with turtles performing $79 \%$ of their dives between 2 and $40 \mathrm{~min}$. In comparison, during migrations, there was more of a pronounced bimodal distribution in dive duration, with peaks between 2 and 5 min (32\%) and between 40 and 60 min (46\%; Fig. 7a). 


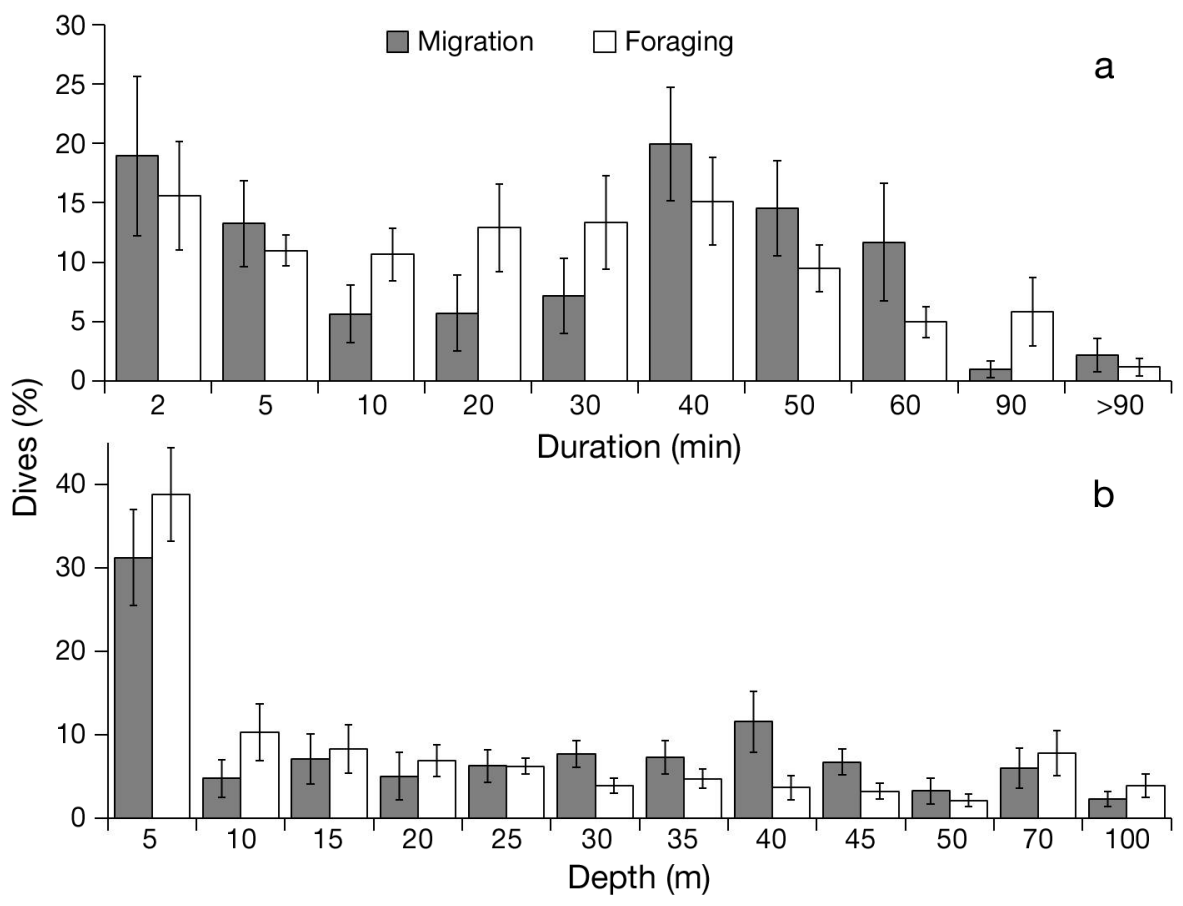

Fig. 7. Chelonia mydas. (a) Duration of dives (min) performed by East $\mathrm{Pa}$ cific green turtles during migration and foraging. We found significant differences between the overall duration of dives, but not between migration and foraging. (b) Depth of dives (m) during migration and foraging. There were significant differences between dive depths, with diving to $5 \mathrm{~m}$ being more frequent than any deeper depths. Error bars $=\mathrm{SE}$

There were also significant differences among the depths to which the dives were performed (ANOVA: $F=11.046 ; \mathrm{df}=12,104 ; \mathrm{p}=0.0001)$. Dives to $5 \mathrm{~m}$ were far more frequent (Bonferroni post hoc multiple comparison: $p<0.0001$ ) than deeper dives (Fig. 7b). Dive depth profiles were similar during post-nesting migrations and while foraging (with no significant difference in the depths of the dives during the migration and foraging phases; ANOVA: $F=1.23$; $\mathrm{df}=12,104 ; \mathrm{p}=0.273$ ). Individuals exhibited variability in diving behavior, using different depths even within the same foraging area, and there was greater variation between individuals than between foraging locations (Fig. 8). Among the turtles foraging in the Gulf of Santa Elena, a majority of dives were to a depth of $5 \mathrm{~m}$, whereas turtles foraging off Honduras, El Salvador, and Guatemala used different depths, ranging from 5 to $80 \mathrm{~m}_{\text {; }}$ while Turtle 3 did not show a strong tendency to use a certain depth, Turtle 6 carried out $52 \%$ of the dives in the first $5 \mathrm{~m}$ of the water column. Turtles foraging in the Gulf of Papagayo used different depth ranges, i.e. Turtle 4 mainly used the first $15 \mathrm{~m}$ of the water column and Turtle 7 dove most frequently to a depth of $70 \mathrm{~m}$.

During migration and foraging, turtles used similar depths during day and night (migration, ANOVA: $F=$ $0.036 ; \mathrm{df}=1,21 ; \mathrm{p}=0.850$ and foraging, ANOVA: $F=$ $0.048 ; \mathrm{df}=1,21 ; \mathrm{p}=0.828)$. Similarly, there were no significant differences in submergence duration between day and night, either during migration (ANOVA: $F=0.001 ; \mathrm{df}=1,17 ; \mathrm{p}=0.973$ ) or during foraging (ANOVA: $F=0.147 ; \mathrm{df}=1,17 ; \mathrm{p}=0.706$ ). It was noted, however, that during foraging, there were 2 predominant durations of dives at night: short dives ( $2 \mathrm{~min}, 22 \%$ ) and long dives (from 20 to $40 \mathrm{~min}$, $49 \%$ ); whereas during the day the duration of the dives varied widely from 5 to $40 \mathrm{~min}$.

\section{DISCUSSION}

This is the first detailed study of post-nesting movements and foraging areas of East Pacific green turtles Chelonia mydas nesting in Costa Rica. Even short-distance movements allowed us to collect valuable information on migratory movements away from the nesting beach, which conveyed at least 9 of the 10 turtles to foraging areas along the Pacific coast of Central America.

\section{Post-nesting movements}

The East Pacific green turtles nesting at Nombre de Jesús, Costa Rica, exhibited at least 3 different migratory strategies, which transported the turtles from 5 to $>1000 \mathrm{~km}$ from the nesting beach. One distinct migratory pattern carried the turtles far north into waters off the coast of Nicaragua, El Salvador, and Guatemala, while another turtle migrated $>1000 \mathrm{~km}$ southward to Panama. A notable finding from this telemetry study is the discovery of a local 

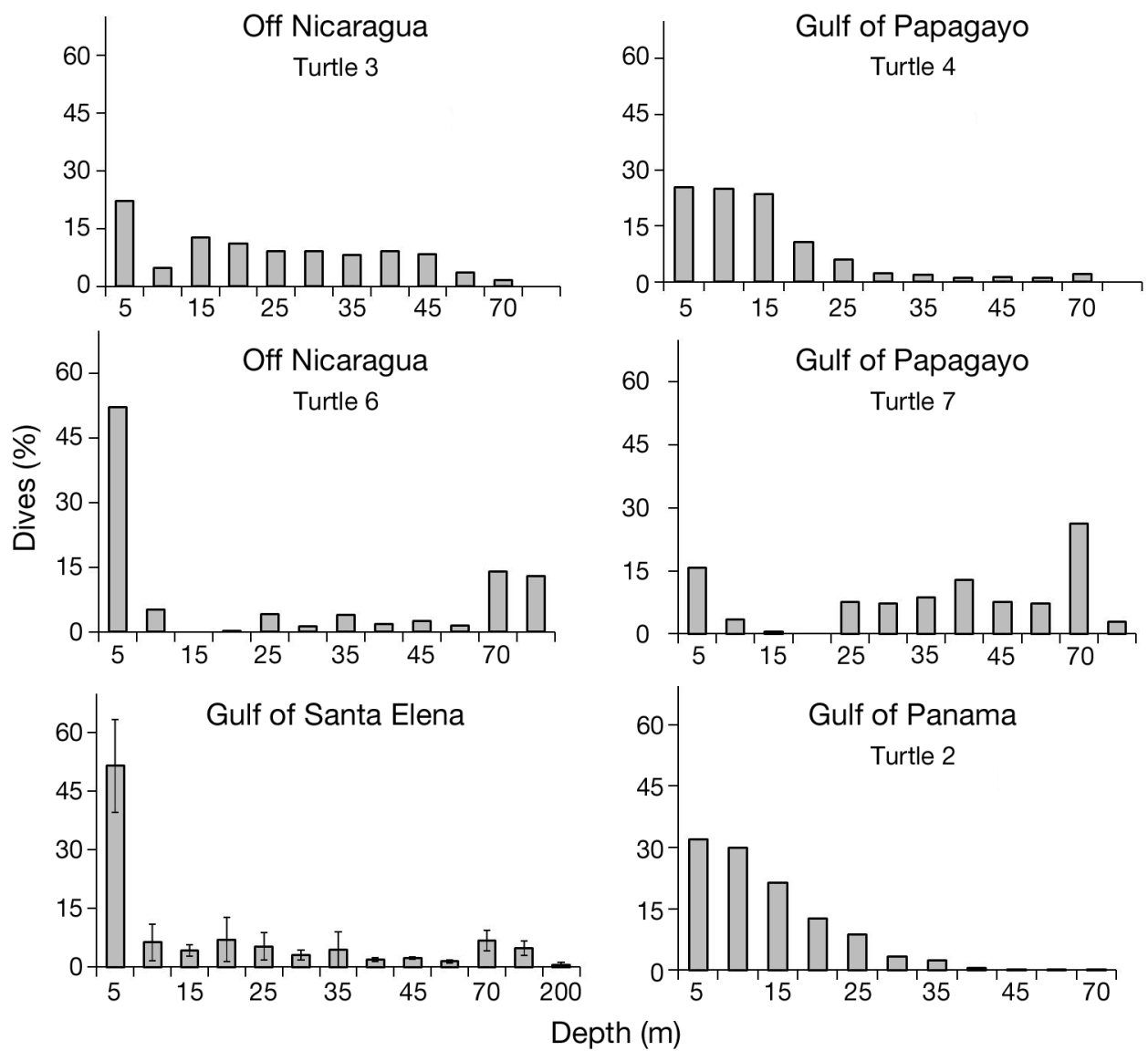

Fig. 8. Chelonia mydas. Depth of submergences of East Pacific green turtles during foraging at different feeding grounds. Turtles 3 and 6 (Off Nicaragua) stopped migratory behavior in the waters off northern Nicaragua but foraged northward. Gulf of Santa Elena shows pooled data for 4 individuals because of the small variation among them (error bars = SE); Gulf of Papagayo, Turtles 4 and 7; Gulf of Panama, Turtle 2

resident population of foraging adult green turtles as close as $5 \mathrm{~km}$ to the nesting beach in the Gulf of Papagayo. We consider the 2 turtles that initiated resident foraging in the Gulf of Papagayo as part of a slightly expanded group that included 4 other individuals that exhibited foraging behavior in the neighboring Gulf of Santa Elena. It is possible that these 6 females are representative of a group of yearround residents of adult green turtles that live off the Pacific coast of northern Costa Rica and southern Nicaragua. Similar residency behavior has also been observed for Pacific green turtles nesting in the Galapagos Islands and remaining within $75 \mathrm{~km}$ of the nesting beach (Seminoff et al. 2008). Migration is driven by ecological factors, such as seasonality, body size, environment, etc. (Alerstam et al. 2003, Dingle \& Drake 2007). But migration also has a high cost in terms of energy (Alerstam et al. 2003). The turtles nesting at Nombre de Jesús probably have the resources needed for survival, such as food availability, environmental conditions, etc. close to the nest- ing beach, and these factors have driven a group of turtles to reside in the same area where they reproduce. This may increase their reproductive frequency in comparison to turtles from the same rookery that migrate longer distances.

Interestingly, it has been reported previously that a green turtle nesting in the Galapagos also migrated to the Gulf of Papagayo (Green 1984), so green turtles from different rookeries in the eastern Pacific may share the same feeding grounds. Indeed, this also appears to be the case for the turtles that exhibited the 2 other migration strategies in the present telemetry study. Two of the 3 turtles that migrated northwards, from 250 to $500 \mathrm{~km}$ from the nesting beach, appeared to settle into a foraging mode in coastal shelf waters extending from northern Nicaragua to southern Guatemala. These same coastal waters off El Salvador and Guatemala have been described previously to be important foraging grounds for green turtles nesting farther north in Michoacán, Mexico (Alvarado \& Figueroa 1992), and for turtles 
nesting in the Galapagos (Seminoff et al. 2008). Also, turtles from the Galapagos and Mexico are known to forage at Gorgona Island, Colombia (Amorocho et al. 2012). Additionally, turtles from the Galapagos are known to move eastwards to the Gulf of Panama (Green 1984, Seminoff et al. 2008), the same region where our southward-migrating turtle remained in foraging mode for at least $45 \mathrm{~d}$ until transmissions ceased.

Post-nesting turtles from this rookery did not undertake oceanic migrations, as has been reported for other populations of post-nesting green turtles (Cheng 2000, Hays et al. 2002). Rather, after nesting in Pacific Costa Rica, female turtles stayed within coastal areas, even when migrating $>1000 \mathrm{~km}$. Although it was not always the shortest distance to the foraging area, all but one of the green turtles migrated along relatively shallow, coastal waters. Nevertheless, variations in strategies exist from population to population. For example, post-nesting green turtles migrating from Tortuguero to Nicaragua, Honduras, and Belize in the Caribbean used both strategies (Troëng et al. 2005). Seven of these turtles migrated through coastal waters, and 3 turtles circled in oceanic waters before migrating northwards (Troëng et al. 2005). This is also the case for Galapagos green turtles (Seminoff et al. 2008). Based on previous information we cannot rule out the possibility of Costa Rican green turtles migrating through oceanic areas.

After nesting in Taiwan, Australia, and Mexico, sea turtles have been reported to stop and forage along the way to their final destination (Cheng 2000, Whiting et al. 2007, Cuevas et al. 2008). Such browsing behavior may reduce the overall cost of migration (Godley et al. 2002) and could explain the differences in migration durations for turtles migrating from Nombre de Jesús to the same feeding grounds. In the present study, several of the turtles migrated through what appeared to be suitable foraging areas, such as the Gulfs of Papagayo and Santa Elena, but continued their northward migrations. Similarly, the turtle that migrated to Panama moved through the coastal waters of Costa Rica, which have been reported as potential foraging areas for green turtles from Mexico (Alvarado \& Figueroa 1992) and the Galapagos (Green 1984). The observed behavior of turtles passing through zones that may offer needed resources in favor of a more distant destination raises the question of how individuals select foraging sites. Studies on other populations have attributed such behavior to food resource limitation, proximity to over-wintering sites, and territorial defense (Broderick et al. 2007). In the present study, we discard the possibility of the turtles being closer to overwintering sites, and we find improbable an explanation of resource limitation, because other turtles stopped and remained to forage in the same areas. In addition, turtle body size is not related to migration distances and ultimate foraging sites, unlike the relationship observed in migrating turtles from Galapagos nesting beaches (Seminoff et al. 2008). Instead, we suggest that the turtles selected these foraging areas as juveniles or sub-adults as a consequence of their early dispersal patterns, and, as adults, continued migrations in response to fidelity to a specific foraging area (Broderick et al. 2007). This may also be the case for resident turtles.

The mean daily speed of travel during migration for this population $\left(\sim 37 \mathrm{~km} \mathrm{~d}^{-1}\right)$, is comparable to that of travel for Galapagos green turtles (Seminoff et al. 2008), and slower than that of green turtles from Tortuguero, Costa Rica, which traveled an average of $58 \mathrm{~km} \mathrm{~d}^{-1}$ to reach foraging grounds (Troëng et al. 2005). Also, green turtles nesting in Taiwan moved an average of $43 \mathrm{~km} \mathrm{~d}^{-1}$ to the continental shelf of China (Cheng 2000). Turtles from the Pacific coast of Costa Rica did not show significant differences in speed of travel related to body size, but, overall, green turtles elsewhere are larger than in the eastern Pacific (Pritchard 1997) and, as a consequence, may travel faster. Greater speed of travel, however, may also reflect a lack of intervening foraging habitats, the need to travel greater distances than turtles at Nombre de Jesús, or whether travel is oceanic or neritic.

\section{Foraging areas}

We identified at least 4 feeding grounds in which there were remarkable differences in the area used. Calculated foraging range sizes varied from 315 to $18335 \mathrm{~km}^{2}$. These home ranges are larger, in general, than those reported for other sea turtles (Seminoff et al. 2002a, Makowski et al. 2006, Whiting et al. 2007).

The 2 turtles that foraged over the largest area did so in 2 very different manners. One of these appeared to begin foraging in coastal waters offshore of Nicaragua and then continued, moving past Honduras and El Salvador to southern Guatemala, displaying ARS behavior the entire time. The KDA analysis showed that this turtle focused on different places within the extended range, presumably exploring patchy food resources in coastal waters. This behavior probably continued, as the turtle was still moving at the end of the transmission, $80 \mathrm{~d}$ after leav- 
ing the beach; therefore, we suggest that the foraging ground for this individual may be larger than the one reported here. In contrast, 1 of the 4 turtles that foraged in the Gulf of Santa Elena extended its foraging area by moving $>200 \mathrm{~km}$ directly offshore to oceanic waters, reaching areas with depths $>4000 \mathrm{~m}$.

At the other extreme was the turtle that moved southwards to Panama and, once there, foraged inside the Gulf of San Miguel using only $315 \mathrm{~km}^{2}$ during $45 \mathrm{~d}$ of foraging. Whereas the turtle in Panama was probably feeding in sea grass pastures and estuary-influenced benthic environments, the turtle that moved far offshore of Santa Elena may have been consuming surface macroalgae and other plankton, such as jellyfish (Quiñones et al. 2010). Overall, differences in the use of foraging areas could be due to different foraging strategies (Godley et al. 2003) and food availability at the different sites or within the same area (Seminoff et al. 2002b). Coral reefs are present along the coasts of Guatemala, El Salvador, Nicaragua, and Costa Rica (Glynn \& Ault 2000). In these regions macroalgae are also present from 0.5 to approximately $20 \mathrm{~m}$ in depth (Fernández \& Alvarado 2008, Bernecker \& Wehrtmann 2009). Patches of coral and the widespread occurrence of rocky reefs, and their associated species of algae and invertebrates, could explain the strong affiliation for shelf waters exhibited by at least 8 of the foraging turtles, i.e. most of their time spent in the foraging mode was in waters shallower than $100 \mathrm{~m}$. Even though we described 4 foraging areas for turtles nesting in Nombre de Jesús, based on previous studies that reported several foraging grounds for East Pacific green turtles (Alvarado \& Figueroa 1992, Seminoff et al. 2002a, López-Mendilaharsu et al. 2005, Seminoff et al. 2008, Amorocho et al. 2012), we believe that this nesting population may have other feeding grounds in addition to those reported here.

\section{Diving behavior}

For turtles within foraging areas, the distribution of dive durations was relatively uniform, ranging from 2 to $90 \mathrm{~min}$, with a tendency toward longer dives at night. The wide variation in dive durations during daytime foraging probably reflected a similar diversity of individual foraging strategies and even different behaviors of the same individual. Besides feeding, turtles carry out other activities, such as resting, moving from patch to patch, exploring the area (Seminoff \& Jones 2006), or even performing selfcleaning behavior (Heithaus et al. 2002). Much of the variation in foraging behavior is likely related to the environmental characteristics of the specific foraging area and the type, quantity, and distribution of food available at the site. For the turtles observed in this study foraging in northern Costa Rica and northwards, the variation in diving patterns was consistent with animals moving from patch to patch, probably feeding among rocky and coral reefs.

Dive depths were much more highly skewed, with a predominance of dives to depths shallower than $5 \mathrm{~m}$ and a vast majority shallower than $30 \mathrm{~m}$. In general, green turtles can forage in benthic environments, ranging from 3 to $32 \mathrm{~m}$, or in the mid-water column (Seminoff et al. 2006). In the present study, foraging turtles probably exhibited both behaviors. The 4 turtles foraging within the Gulf of Santa Elena probably foraged on the bottom while in the nearshore environment. However, when 2 of the turtles from that area made excursions to deep-water environments, they continued to dive only to shallow depths, indicating that they were foraging on surface or mid-water animals, or floating algae. A similar, shallow-water diving pattern was observed in all of the coastal areas, reinforcing the view of turtles moving from patch to patch, feeding mainly in shallow waters on the bottom or on reefs. In addition, the proportion of shallow and short dives at night within foraging areas indicated that these turtles were not trying to achieve neutral buoyancy in deeper water to rest (Hays et al. 2000), but were resting very close to or at the surface, similar to the unique internesting behavior reported for this same nesting population (Blanco et al. in press).

\section{Conservation implications}

The Endangered East Pacific green turtles nesting in northwestern Costa Rica may spend all of their life as adults in coastal areas of Central America, and, thus, the coastal nature of their movements makes them vulnerable to human activities. Declines in different populations of sea turtles in the region, from both the Pacific and Caribbean coasts, have been attributed to bycatch by fisheries, both industrial and local (Spotila et al. 2000, Lewison et al. 2004, Troëng et al. 2005, Wallace et al. 2010). Additionally, one of the identified threats for green turtles in the Pacific is the incidental capture from coastal fisheries (Chaloupka et al. 2004). There is a lack of information on the interaction between East Pacific green turtles and fisheries in Central America. Swimmer et al. (2006) recovered a number of olive ridleys caught in shallow set gear 
along the Pacific coast of Costa Rica, and Koch et al. (2006) reported high sea turtle bycatch in Baja California, Mexico. Capture of internesting East Pacific green turtles in artisanal fishing gear has previously been reported (Blanco et al. in press). The information provided in the present study suggests that there may be frequent interactions among East Pacific green turtles and artisanal fisheries that operate in coastal waters, extending from northern Costa Rica to at least as far north as southern Guatemala. The fact that migrating and foraging turtles swim through the waters of several countries makes management interventions more complex and calls for conservation and fisheries bycatch reduction agreements among several nations. Undoubtedly, more information is needed in order to understand the severity of the impacts of coastal fishing and to develop a targeted and effective management strategy for this Endangered population.

Acknowledgements. We thank principal investigators and field assistants for the leatherback project at Parque Nacional Marino Las Baulas (PNMB), particularly P. Santidrián Tomillo, W. Mendez, S. Valentine, J. Holding, T. Backoff, S. Friederichs, N. Robinson, and C. Campana, and PI's and field assistants for the black turtle project, especially R. Piedra, E. Vélez, L. and J. Morreale and E. Molina M. and W. Villachica $\mathrm{M}$. We are grateful to the park rangers of PNMB, Ministerio de Ambiente, Energía y Telecomunicaciones (MINAET) and Earthwatch volunteers. This project was funded by the Betz Chair Endowment of Drexel University, The Leatherback Trust, and the Wildlife Conservation Society. Thanks to the Goldring Gund Marine Biology Station for accommodations and research facilities. This project was conducted under MINAET permits (ACT-PNMB-005-2007; ACT-SASP-PI-195; ACT-SASP-PI 278; ACT-OR-D-050) and approved by the Animal Care committee of Drexel University.

\section{LITERATURE CITED}

Alerstam T, Hedenström A, Åkesson S (2003) Long-distance migration: evolution and determinants. Oikos 103: 247-260

Alvarado J, Figueroa A (1992) Recapturas post-anidatorias de hembras de tortuga marina negra (Chelonia agassizii) marcadas en Michoacán, Mexico. Biotropica 24:560-566

Alvarado-Díaz J, Delgado-Trejo C, Suazo-Ortuño I (2001) Evaluation of the black turtle project in Michoacán, México. Mar Turtle Newsl 92:4-7

> Amorocho DF, Reina RD (2007) Feeding ecology of the East Pacific green sea turtle Chelonia mydas agassizii at Gorgona National Park, Colombia. Endang Species Res 3:43-51

Amorocho DF, Abreu-Grobois FA, Dutton PH, Reina RD (2012) Multiple distant origins for green sea turtles aggregating off Gorgona Island in the Colombian eastern Pacific. PLoS ONE 7:e31486

Bailey H, Shillinger G, Palacios D, Bograd S, Spotila J, Paladino F, Block B (2008) Identifying and comparing phases of movement by leatherback turtles using state- space models. J Exp Mar Biol Ecol 356:128-135

Bailey H, Mate BR, Palacios DM, Irvine L, Bograd SJ, Costa DP (2009) Behavioural estimation of blue whale movements in the Northeast Pacific from state-space model analysis of satellite tracks. Endang Species Res 10: 93-106

Bernecker A, Wehrtmann I (2009) New records of benthic marine algae and cyanobacteria for Costa Rica, and a comparison with other Central American countries. Helgol Mar Res 63:219-229

Bjorndal KA (1997) Foraging ecology and nutrition of sea turtles. In: Lutz PL, Musick JA (eds) The biology of sea turtles. CRC Press, Boca Raton, FL, p 199-231

Blanco GS (2010) Movements and behavior of the East Pacific green turtle (Chelonia mydas) from Costa Rica. PhD dissertation, Drexel University, Philadelphia, PA

> Blanco GS, Morreale SJ, Vélez E, Piedra R, Montes WM, Paladino FV, Spotila JR (2012) Reproductive output and ultrasonography of an endangered population of East Pacific green turtles. J Wildl Manag 76:841-846

Blanco GS, Morreale SJ, Seminoff JA, Paladino FV, Piedra R, Spotila JR (in press) Movements and diving behavior of internesting green turtles (Chelonia mydas) along Pacific Costa Rica. Integr Zool

Broderick AC, Coyne MS, Fuller WJ, Glen F, Godley BJ (2007) Fidelity and over-wintering of sea turtles. Proc Biol Sci 274:1533-1539

Chaloupka M, Dutton P, Nakano H (2004) Expert consultation on interactions between sea turtles and fisheries within an ecosystem context. FAO Fisheries Report, FAO, Rome

> Cheng IJ (2000) Post-nesting migrations of green turtles (Chelonia mydas) at Wan-an Island, Penghu Archipelago, Taiwan. Mar Biol 137:747-754

Cornelius SE (1976) Marine turtle nesting activity at Playa Naranjo, Costa Rica. Brenesia 8:1-27

- Cuevas E, Abreu-Grobois FA, Guzmán-Hernández V, Liceaga-Correa MA, van Dam RP (2008) Post-nesting migratory movements of hawksbill turtles Eretmochelys imbricata in waters adjacent to the Yucatan Peninsula, Mexico. Endang Species Res 10:123-133

> Dingle H, Drake VA (2007) What is migration? Bioscience 57:113-121

Eguchi T, Seminoff J, LeRoux R, Dutton P, Dutton D (2010) Abundance and survival rates of green turtles in an urban environment: coexistence of humans and an endangered species. Mar Biol 157:1869-1877

Fernández C, Alvarado JJ (2008) Chlorophyta de la Costa Pacífica de Costa Rica. Rev Biol Trop 56:149-162

$>$ Glynn PW, Ault JS (2000) A biogeographic analysis and review of the Far Eastern Pacific coral reef region. Coral Reefs 19:1-23

> Godley BJ, Richardson S, Broderick AC, Coyne MS, Glen F, Hays GC (2002) Long-term satellite telemetry of the movements and habitat utilisation by green turtles in the Mediterranean. Ecography 25:352-362

Godley BJ, Lima EHSM, Åkesson S, Broderick AC and others (2003) Movement patterns of green turtles in Brazilian coastal waters described by satellite tracking and flipper tagging. Mar Ecol Prog Ser 253:279-288

> Green D (1984) Long-distance movements of Galapagos green turtles. J Herpetol 18:121-130

> Hays GC, Adams CR, Broderick AC, Godley BJ, Lucas DJ, Metcalfe JD, Prior AA (2000) The diving behaviour of green turtles at Ascension Island. Anim Behav 59:577-586 
Hays GC, Broderick AC, Godley BJ, Lovell P, Martin C, McConnell BJ, Richardson S (2002) Biphasal long-distance migration in green turtles. Anim Behav 64:895-898

Heithaus MR, McLash JJ, Frid A, Dill LM, Marshall GJ (2002) Novel insights into green sea turtle behaviour using animal-borne video cameras. J Mar Biol Assoc UK 82:1049-1050

- Holroyd GL, Trefry HE (2010) The importance of Isla Clarión, Archipelago Revillagigedo, Mexico, for green turtle (Chelonia mydas) nesting. Chelonian Conserv Biol 9: 305-309

IUCN (International Union for the Conservation of Nature) (2010) IUCN Red List of Threatened Species, Version 2010.2. Available at: www.iucnredlist.org (accessed 10 February 2012)

Jonsen ID, Fleming JM, Myers RA (2005) Robust state-space modeling of animal movement data. Ecology 86: 2874-2880

> Jonsen ID, Myers RA, James MC (2007) Identifying leatherback turtle foraging behaviour from satellite-telemetry using a switching state-space model. Mar Ecol Prog Ser 337:255-264

> Koch V, Nichols WJ, Peckham H, de la Toba V (2006) Estimates of sea turtle mortality from poaching and bycatch in Bahía Magdalena, Baja California Sur, Mexico. Biol Conserv 128:327-334

> Lewison RL, Crowder LB, Read AJ, Freeman SA (2004) Understanding impacts of fisheries bycatch on marine megafauna. Trends Ecol Evol 19:598-604

Logan P, Morreale SJ (1994) Hydrodynamic drag characteristics of juvenile L. kempii, C. mydas and C. caretta. In: Proc 13th Ann Symp Sea Turtle Biology and Conservation. NMFS-SEFSC-341. NOAA, Washington, DC, p 205-208

López-Mendilaharsu M, Gardner SC, Seminoff JA, Riosmena-Rodriguez R (2005) Identifying critical foraging habitats of the green turtle (Chelonia mydas) along the Pacific coast of the Baja California Peninsula, Mexico. Aquat Conserv 15:259-269

Lunn DJ, Thomas A, Best N, Spiegelhalter D (2000) Winbugs-a Bayesian modelling framework: concepts, structure, and extensibility. Stat Comput 10:325-337

Makowski C, Seminoff J, Salmon M (2006) Home range and habitat use of juvenile Atlantic green turtles (Chelonia mydas L.) on shallow reef habitats in Palm Beach, Florida, USA. Mar Biol 148:1167-1179

Morreale SJ (1999) Oceanic migration of sea turtles. Dissertation, Cornell University, Ithaca, NY

Morreale SJ, Standora EA, Spotila JR, Paladino FV (1996) Migration corridor for sea turtles. Nature 384:319-320

Patterson TA, Thomas L, Wilcox C, Ovaskainen O, Matthiopoulos J (2008) State-space models of individual animal movement. Trends Ecol Evol 23:87-94

Pritchard PCH (1997) Evolution, phylogeny, and current status. In: Lutz PL, Musick JA (eds) The biology of sea

Editorial responsibility: Matthew Godfrey,

Beaufort, North Carolina, USA turtles, Vol I. CRC Press, Boca Raton, FL, p 1-50

Quiñones J, González Carman V, Zeballos J, Purca S, Mianzan H (2010) Effects of El Niño-driven environmental variability on black turtle migration to Peruvian foraging grounds. Hydrobiologia 645:69-79

R Development Core Team (2008) R: a language and environment for statistical computing. R Foundation for Statistical Computing, Vienna. www.R-project.org

Richard JD, Hughes DA (1972) Some observations of sea turtle nesting activity in Costa Rica. Mar Biol 16:297-309

Rodgers AR, Carr AP, Smith L, Kie JG (2005) Hrt: home range tools for ArcGIS. Ontario Ministry of Natural Resources, Centre for Northern Forest Ecosystem Research, Thunder Bay, Ontario

Seminoff JA, Jones TT (2006) Diel movements and activity ranges of green turtles (Chelonia mydas) at a temperate foraging area in the Gulf of California, Mexico. Herpetol Conserv Biol 1:81-88

Seminoff JA, Resendiz A, Nichols WJ (2002a) Home range of green turtles Chelonia mydas at a coastal foraging area in the Gulf of California, Mexico. Mar Ecol Prog Ser 242: 253-265

Seminoff JA, Resendiz A, Nichols WJ (2002b) Diet of east Pacific green turtles (Chelonia mydas) in the central Gulf of California, Mexico. J Herpetol 36:447-453

Seminoff JA, Jones TT, Marshall GJ (2006) Underwater behaviour of green turtles monitored with video-timedepth recorders: what's missing from dive profiles? Mar Ecol Prog Ser 322:269-280

Seminoff JA, Zárate P, Coyne M, Foley DG, Parker D, Lyon BN, Dutton PH (2008) Post-nesting migrations of Galápagos green turtles Chelonia mydas in relation to oceanographic conditions: integrating satellite telemetry with remotely sensed ocean data. Endang Species Res 4: $57-72$

Spotila JR, Reina RD, Steyermark AC, Plotkin PT, Paladino FV (2000) Pacific leatherback turtles face extinction. Nature 405:529-530

Swimmer Y, Arauz R, McCracken M, McNaughton L and others (2006) Diving behavior and delayed mortality of olive ridley sea turtles Lepidochelys olivacea after their release from longline fishing gear. Mar Ecol Prog Ser 323:253-261

Troëng S, Evans DR, Harrison E, Lagueux CJ (2005) Migration of green turtles Chelonia mydas from Tortuguero, Costa Rica. Mar Biol 148:435-447

Wallace BP, Lewison RL, McDonald SL, McDonald RK and others (2010) Global patterns of marine turtle bycatch. Conserv Lett 3:131-142

> Whiting SD, Long JL, Coyne M (2007) Migration routes and foraging behaviour of olive ridley turtles Lepidochelys olivacea in northern Australia. Endang Species Res 3:1-9

> Worton BJ (1989) Kernel methods for estimating the utilization distribution in home-range studies. Ecology 70 : $164-168$

Submitted: February 23, 2012; Accepted: July 18, 2012 Proofs received from author(s): September 11, 2012 